Article

\title{
Identification of Microflora in a Biological Brewer's Wort Acidification Process Run Continuously for 20 Years
}

\author{
Mathias Hutzler ${ }^{1, *}+\dagger^{(1 D}$, Jana Čmielová ${ }^{2,+}$, Tobias Frank ${ }^{3}$, Andreas Brandl ${ }^{4}$, Fritz Jacob ${ }^{1}$ and \\ Maximilian Michel ${ }^{1}$ \\ 1 Research Center Weihenstephan for Brewing and Food Quality, Technische Universität München, Alte \\ Akademie 3, 85354 Freising, Germany; f.jacob@tum.de (F.J.); m.michel@tum.de (M.M.) \\ 2 Department of Microbiology, Research Institute of Brewing and Malting, PLC, Lípová 15, 12044 Prague, \\ Czech Republic; jana.cmielova.211@gmail.com \\ 3 Ottakringer Brauerei AG, Ottakringer Platz 1, 1160 Vienna, Austria; tobias.frank@ottakringer.at \\ 4 Doemens Academy GmbH, Stefanusstraße 8, 82166 Gräfelfing, Germany; brandl@doemens.org \\ * Correspondence: m.hutzler@tum.de \\ + These authors contributed equally to this work.
}

Received: 8 June 2018; Accepted: 30 June 2018; Published: 4 July 2018

\begin{abstract}
Biological acidification is a common and beneficial way for breweries to adjust the $\mathrm{pH}$ value of their mash or wort to improve enzymatic activity during mashing, raise yeast activity during fermentation, and increase the flavor stability of the finished beer. The reactors are mostly run for many years without re-inoculating a fresh culture, creating the possibility of changes in the culture, genetic drifts, or the survival of different strains. In this study, a biological acidification culture that had been continuously run for 20 years was analyzed by GTG5 PCR and IGS2-314 rDNA PCR fingerprinting, as well as $16 \mathrm{~S}$ and $26 \mathrm{~S}$ rDNA sequencing, and real-time PCR was applied to differentiate the bacterial and yeast strains and species. The applied real-time PCR primers for Lactobacillus amylolyticus and Lactobacillus amylovorus have not been published yet. It was shown that only strains of the species L. amylolyticus were present, with low contamination of yeast strains from the species Saccharomyces cerevisiae. As the original starter culture was Lactobacillus amylolyticus, the acidification plant ran for 20 years, and no Lactobacillus sp. cross-contamination could be analyzed using culture-dependent methods after 20 years. The microflora composition is a decisive factor for the final beer flavor.
\end{abstract}

Keywords: microflora; biological acidification; L. amylolyticus

\section{Introduction}

Deliberate biological mash acidification has a major positive impact on almost all steps in the brewery, from mashing through to the final beer [1]. It is caused by thermophilic lactic acid bacteria (LAB), which were first described approximately 130 years ago by P. Lindner [2]. Twelve years later, in 1896, Leichmann found bacterial cells producing lactic acid from malt mash [3]. Since then, it has become a widely used technique for improving the quality of beer and lowering the $\mathrm{pH}$ of the malt, sweet wort, and wort in the brewery. The first patent for an applied wort acidification process was claimed in 1906 by Otto Francke [4]. The process consists of a batch or continuous fermentation of diluted sweet wort $\left(5-12^{\circ} \mathrm{P}\right)$ by a culture of $\mathrm{LAB}$, to a final concentration of $1 \%$ lactic acid. Acidification is usually complete within $24 \mathrm{~h}$, and achieves a final $\mathrm{pH}$ value of $3.0-3.6$ [1,5]. A ratio of $1-2 \%$ acidified sweet wort is added to acidify mash or wort. This addition changes the mash $\mathrm{pH}$ value by $0.1-0.3 \mathrm{pH}$ units, and the wort $\mathrm{pH}$ value by $0.2-0.4 \mathrm{pH}$ units [1] As the LAB applied are very sensitive to hops, 
and the mixture is heated to temperatures that are lethal to bacteria, an infection of the final product is unlikely [1]. Biological acidification is a natural way of adding lactic acid to the brew instead of using technical lactic or phosphoric acid to lower the $\mathrm{pH}$ value. It is therefore accepted under the German Purity Law (Reinheitsgebot), and is used by many German breweries as well as breweries around the world [6].

The benefits of biological acidification are, in particular, better fermentation, higher selective pressure on the yeast, better enzyme offerings, and activities in the mash (glucanolytic, proteolytic, and amylolytic), as well as good nutrient supply, filtration, sensory quality, and flavor stability of the beer in comparison with technical acidification (lactic and phosphoric acid) [7-10]. There are also minor disadvantages with biological acidification, such as a loss of bitter substances, lower hop isomerization, and a lower splitting range of DMS (dimethyl sulfide) precursors [9].

The most employed microorganism, Lactobacillus amylolyticus, originated from barley malt, but other LAB are also used, i.e., L. delbrueckii, L. fermentum, L. casei, L. amylovorus, L. helveticus, Pediococcus acidilacti, P. pentosaceus, and P. dextrinicus [1,7,11,12]. Important requirements in the selection of LAB strains are the production of the maximum amounts of $\mathrm{L}(+)$-lactic acid as a metabolic end product, with relatively low or no production of diacetyl; it must be a natural isolate from barley or malt, and growth should be at $47-48^{\circ} \mathrm{C}[10,12]$. Strains of the species L. amylolyticus are Gram-positive rods, catalase- and oxidase-negative, homofermentative, thermophilic, and microaerophilic-they ferment maltose, dextrins, and starch, and are sensitive to hop compounds. In comparison with yeast propagation, which is re-inoculated with a fresh culture of pure yeast approximately every four months [13]; biological acidification is left to its own devices for many years by most breweries. The low pH value, as well as the high temperature, ensures a microbiologically stable process with a low contamination risk [1]. Moreover, most breweries using biological acidification report a typical "in-house taste" [6] that is related to their acidification process, and which could change after re-inoculating the LAB. This incidence could be due to strain-related flavor production or to contamination by thermophilic yeast (Kluyveromyces marxianus or Candida kefyr) other thermophilic bacteria (L. casei subspecies or L. coryniformis), or by a mixture of differing strains of the same species [1,6].

The aim of this study was therefore to identify the species of microorganisms in the biologically acidified sweet wort samples that had been continuously used for 20 years for biological acidification without re-inoculation in the Ottakringer brewery (Vienna, Austria).

\section{Materials and Methods}

\subsection{Media and Growth Conditions}

Two biologically acidified sweet wort samples were supplied by the Ottakringer brewery in Vienna, Austria. Each of the samples was serially diluted using 10-fold volumes of physiological salt solution and cultured on wort agar with tetracycline (WAT) $(20 \mu \mathrm{L} / \mathrm{mL})$ (Weihenstephan Brewery, Freising, Germany), on sweet wort agar (SW) at $11^{\circ} \mathrm{P}$ (Weihenstephan Brewery), and MRS agar (Sifin, Berlin, Germany) using the spread plate technique. Cultivation was performed at 28 and $48^{\circ} \mathrm{C}$ under aerobic (WAT) and anaerobic (WAT, SW, and MRS) conditions for 2-7 days. Anaerobic cultivation was performed with Anaerocult A (Merck, Darmstadt, Germany) in a 2.5 L anaerobiosis jar (Merck). Microorganisms with distinct colony morphologies were selected, and the cell morphology was microscopically determined. The isolates were sub-cultured in the same medium and used as stock cultures in subsequent analyses. Yeasts were numbered in the following from sample SG1 to SG100. All bacteria are numbered starting from SG 101 and continuing in ascending order.

\subsection{Preparing Cryogenic Cultures}

Single colonies were inoculated into liquid media, and the growth cultures were used to prepare cryogenic cultures-Roti-Store yeast cryo-vials (Roth, Karlsruhe, Germany) for yeasts, and a Roti-Store cryo-vial (Roth) for bacteria. The cultures were stored at $-80^{\circ} \mathrm{C}$. 


\subsection{PCR and Fingerprinting}

DNA isolation was executed as follows: microbial cultures $(100 \mu \mathrm{L})$ were transferred into sterile reaction vessels and centrifuged at $12,000 \times g$ for $2 \mathrm{~min}$; cell pellets were re-suspended in the InstaGene Matrix (Biorad, München, Germany). DNA was then isolated according to the manufacturer's instructions and was used for fingerprint typing, real-time PCR, and for 16S rDNA and 26S rDNA sequence analyses.

The DNA concentration was measured spectrophotometrically at 230, 260, and $280 \mathrm{~nm}$ (Nanodrop 1000, Thermo Scientific, Waltham, MA, USA) and adjusted to $25 \mathrm{ng} / \mu \mathrm{L}$ for (GTG) ${ }_{5}$ analysis. The primer (GTG) $)_{5}$ (Table 1) and the following PCR protocol were used: (i) $95^{\circ} \mathrm{C}$ for $5 \mathrm{~min}$; (ii) 30 cycles of $95^{\circ} \mathrm{C}$ for $30 \mathrm{~s}, 40^{\circ} \mathrm{C}$ for $1 \mathrm{~min}$, and $72{ }^{\circ} \mathrm{C}$ for $8 \mathrm{~min}$; (iii) $72{ }^{\circ} \mathrm{C}$ for $16 \mathrm{~min}$. For IGS2-314 analysis, the primers IGS2-314-fp and IGS2-314-rp (Table 1) were used, and the PCR parameters were (i) $95^{\circ} \mathrm{C}$ for 5 min; (ii) 35 cycles of $95{ }^{\circ} \mathrm{C}$ for $25 \mathrm{~s}, 54{ }^{\circ} \mathrm{C}$ for $30 \mathrm{~s}$, and $72{ }^{\circ} \mathrm{C}$ for $40 \mathrm{~s}$; and (iii) $72{ }^{\circ} \mathrm{C}$ for $5 \mathrm{~min}$.

PCR was carried out using the MasterCycler manufactured by Eppendorf in Germany. PCR master mixes were prepared with a $12.5 \mu \mathrm{L}$ RedTaq Master Mix 2x (Genaxxon, Ulm, Germany), $5 \mu \mathrm{L}$ water at PCR quality, $5 \mu \mathrm{L}$ of primer (Biomers, Ulm, Germany), and $2.5 \mu \mathrm{L}$ of template DNA, resulting in a total reaction volume of $25 \mu \mathrm{L}$ for (GTG) 5 analysis; and with $12.5 \mu \mathrm{L}$ RedTaq Master Mix $2 x$ (double concentrated) (Genaxxon), $7 \mu \mathrm{L}$ of water (PCR quality), 2,5 $\mu \mathrm{L}$ of each primer (Biomers) and $2.5 \mu \mathrm{L}$ of template DNA, resulting in a total reaction volume of $25 \mu \mathrm{L}$ for IGS2 314 analysis.

Amplicons were initially analyzed by the gel electrophoresis system Agilent 2100 (Agilent Technologies, Santa Clara, CA, United States), using the Agilent DNA 7500 kit ((GTG) 5 analysis) and the Agilent DNA 1000 kit (IGS2 314 analysis). Phylogenetic analysis was conducted using Bionumerics 7.1 software (Applied Maths, Sint-Martens-Latem, Belgium). The sequence similarity was estimated using the Pearson correlation with an optimization of $0.5 \%$ and curve smoothing of $0.5 \%$, and the cluster analysis was constructed using the UPGMA (Unweighted Pair Group Method with Arithmetic Mean) method with highest overall similarity.

Table 1. Primers used in this work.

\begin{tabular}{ccc}
\hline Primer & Sequence $\mathbf{5}^{\prime} \rightarrow \mathbf{3}^{\prime}$ & Reference \\
\hline GTG 5 & GTGGTGGTGGTGGTG & {$[14]$} \\
\hline IGS2-314-fp & $\begin{array}{c}\text { CGGGTAACCCAGTTCCTCACT } \\
\text { GTAGCATATATTTCTTGTGTGAGAAAGGT }\end{array}$ & {$[15]$} \\
\hline IGS2-314-rp & AGAGTTTGATCM(C/A)TGGCTCAG & {$[16]$} \\
\hline $16 S-27 f$ & TACGGY(C/T)TACCTTGTTACGACTT & {$[17]$} \\
\hline $1492 \mathrm{r}$ & GTAAGGTTY(C/T)TNCGCGT & {$[18]$} \\
\hline $612 \mathrm{r}$ & CCGTCAATTCM(C/A)TTTRAGT & {$[19]$} \\
\hline $926 \mathrm{r}$ & GCATATCAATAAGCGGAGGAAAAG & \\
\hline $\mathrm{NL1}$ & GGTCCGTGTTTCAAGACGG &
\end{tabular}

\subsection{Sequencing of $16 S$ and $26 S$ rDNA}

The primers 16S-27f and 1492r (Table 1) were used for the analysis of $16 \mathrm{~S}$ rDNA and bacteria identification, and the PCR parameters were chosen as follows: (i) $95^{\circ} \mathrm{C}$ for $5 \mathrm{~min}$; (ii) 35 cycles of $95^{\circ} \mathrm{C}$ for $25 \mathrm{~s}, 55^{\circ} \mathrm{C}$ for $40 \mathrm{~s}$, and $72{ }^{\circ} \mathrm{C}$ for $2 \mathrm{~min}$; and (iii) $72{ }^{\circ} \mathrm{C}$ for $5 \mathrm{~min}$.

The primers NL1 and NL4 (Table 1) were used for the analysis of 26S rDNA of the yeast, and the following protocol was used for the PCR: (i) $95^{\circ} \mathrm{C}$ for $5 \mathrm{~min}$; (ii) 35 cycles of $95^{\circ} \mathrm{C}$ for $25 \mathrm{~s}, 5{ }^{\circ} \mathrm{C}$ for $1 \mathrm{~min}$, and $72{ }^{\circ} \mathrm{C}$ for $1 \mathrm{~min}$; and (iii) $72{ }^{\circ} \mathrm{C}$ for $10 \mathrm{~min}$.

PCR was carried out using a thermal cycler (MasterCycler, Eppendorf, Hamburg, Germany). PCR was performed with $25 \mu \mathrm{L}$ of RedTaq Master Mix 2x (Genaxxon), $16 \mu \mathrm{L}$ of PCR-clean water, $2 \mu \mathrm{L}$ 
of each primer (Biomers) and $5 \mu \mathrm{L}$ of template DNA, for a total reaction volume of $50 \mu \mathrm{L}$. The PCR products were purified using the QIAquick PCR purification kit (Qiagen, Hilden, Germany), according to the manufacturer's instructions. The DNA concentration was measured spectrophotometrically at 230, 260, and $280 \mathrm{~nm}$ (Nanodrop 1000, Thermo Scientific, United States), and adjusted to 20-80 ng/ $\mu \mathrm{L}$. For sequencing, $5 \mu \mathrm{L}$ of diluted primer $(5 \mathrm{pmol} / \mu \mathrm{L}) \mathrm{NL} 4$ for yeasts or $1492 \mathrm{r}$, $612 \mathrm{r}$, or $926 \mathrm{r}$ for bacteria were added to $5 \mu \mathrm{L}$ of purified PCR product. Sequencing was carried out by GATC Biotech, Germany. The resulting $16 \mathrm{~S}$ rDNA and $26 \mathrm{~S}$ rDNA sequences were analyzed using the Basic Local Alignment Search Tool (BLAST) (http:/ / www.ncbi.nlm.nih.gov/blast/) in the GenBank nonredundant/nucleotide collection (nr/nt).

\subsection{Real-Time PCR}

Species classification was verified using real-time PCR (Light Cycler 480 II, Roche, Penzberg, Germany). Primer and probe sequences for species Lactobacillus amylovorus (Lavo-f (5'-CCCCAAAGTCTGGGATACCAT-3'), Lp-r $\quad\left(5^{\prime}\right.$-ATTCCCTACTGCTGCCTCCC- $\left.3^{\prime}\right)$, i200(FAM) (5'-CCACATTGGGACTGAGACACGGCC-3')) and L. amylolyticus (Laly-f (5'-AAGTGCTGCATGGCACTTGC-3'), Lp-r, i200(FAM)) were used according to Brandl [20]. The yeast identification was confirmed according to Hutzler [15] and Salinas [21] by the following PCR-systems: UG-LRE1, UG300, OG-COXII, Sbp, and SCTM. Real-time PCR was performed with $10 \mu \mathrm{L}$ of $2 x$ Master Mix (Light Cycler 480 Probe Master, Roche), $3 \mu \mathrm{L}$ of PCR-clean water, $0.8 \mu \mathrm{L}$ of each primer (Biomers), $0.4 \mu \mathrm{L}$ of probe (Biomers) and $5 \mu \mathrm{L}$ of template DNA in a total reaction volume of $20 \mu \mathrm{L}$. Real-time PCR parameters were adjusted to (i) $95^{\circ} \mathrm{C}$ for $10 \mathrm{~min}$, (ii) 40 cycles of $95^{\circ} \mathrm{C}$ for $10 \mathrm{~s}$, and (iii) $60{ }^{\circ} \mathrm{C}$ for $55 \mathrm{~s}$.

\subsection{Phenolic Off-Flavor Test}

For the stock solution of ferulic/cinnamic acid, $1 \mathrm{~g}$ of the instant phenolic acid was diluted in $20 \mathrm{~mL}$ of $96 \%(v / v)$ ethanol. Then $2 \mathrm{~mL}$ of the stock solution was added to $1000 \mathrm{~mL}$ yeast and mold (YM) agar media (add distilled water to $3.0 \mathrm{~g}$ malt extract, $3.0 \mathrm{~g}$ yeast extract, $5.0 \mathrm{~g}$ peptone, $11.0 \mathrm{~g}$ glucose monohydrate, and $20.0 \mathrm{~g}$ agar, to $1000 \mathrm{~mL}$ ) at $45-50{ }^{\circ} \mathrm{C}$ under sterile conditions. The investigated pure yeast strains were taken from the agar plates and spread on the $\mathrm{YM}$ agar plate containing the described acid. Samples were incubated for three days at $28^{\circ} \mathrm{C}$. LeoBavaricus-TUM $68^{\circledR}$ (a common phenolic off-flavor (POF)-positive wheat beer strain [22]) and Frisinga-TUM 34/70 ${ }^{\circledR}$ were also taken into account as a positive (TUM 68) and a negative (TUM 34/70) control. Evaluation was performed by seven trained panelists, who judged the smell of the plates with 4-vinylguaiacol (4-VG; clove-like) or 4-vinylstyrene (4-VS; styrofoam-like) positive or negative.

\section{Results}

The aim of this study was to identify the species and strains of microorganisms in the biological acidification reactor that were continuously used for 20 years without re-inoculation in the Ottakringer brewery (Vienna, Austria). A total of 22 of the 50 microorganism isolates recovered from biologically acidified sweet wort samples were microscopically identified as yeasts, and 28 isolates were identified as LAB.

\subsection{Identification of Bacteria}

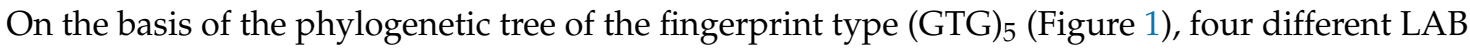
were chosen for further analyses (SG109, SG115, SG126, and SG139). As can be seen, the strains are divided into two main clusters that had a similarity of $78 \%$. A similarity value of $>70 \%$ implies that all the strains belong to the same species [23]. Therefore, two strains of each cluster were chosen for further analyses. 


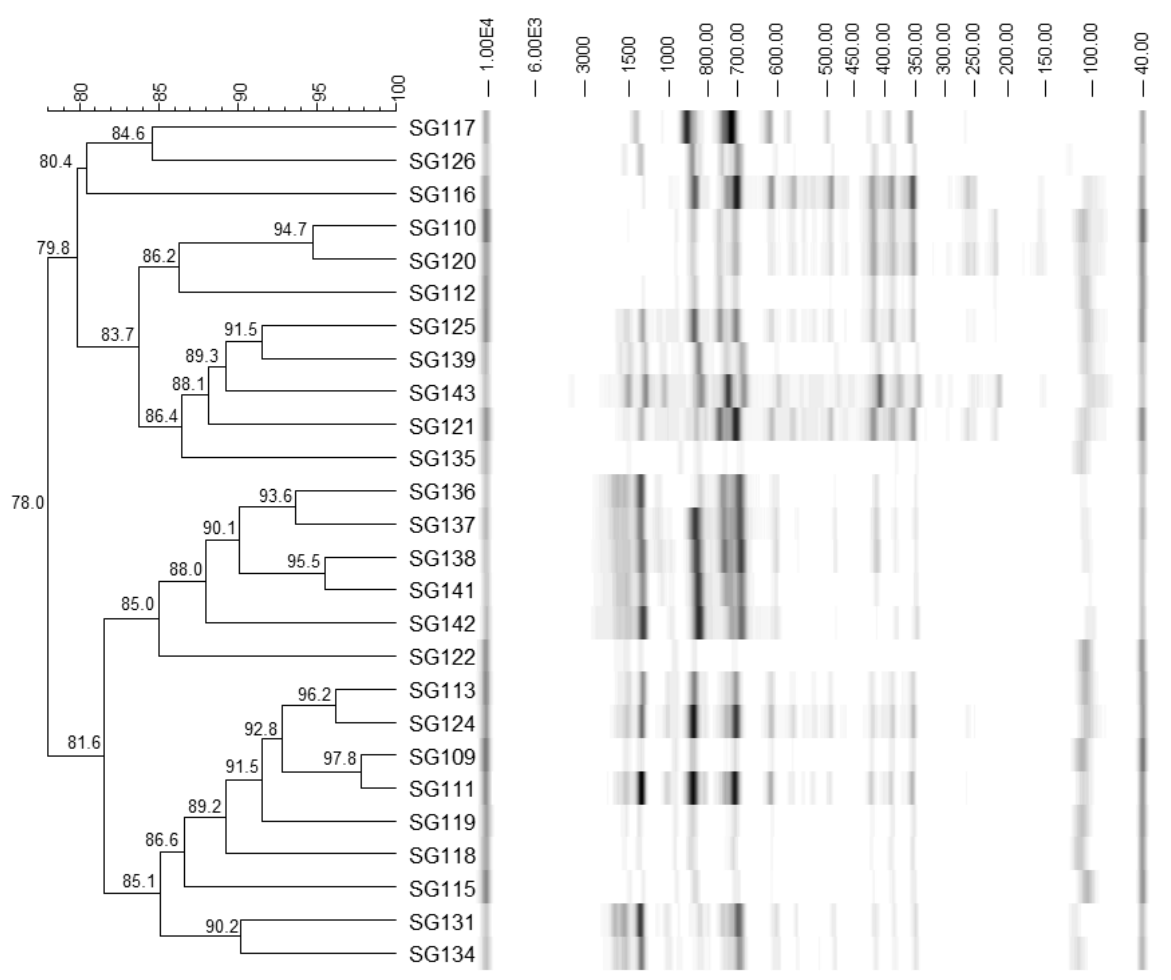

Figure 1. Phylogenetic tree $\left((\mathrm{GTG})_{5}\right)$ of the 28 lactic acid bacteria samples found in the sample of acidified wort, identified by sequencing (16S rDNA) as Lactobacillus amylolyticus.

The primer 1492r (see Table 1) was used for the 16S rDNA gene sequencing. The results of BLAST are shown in Table 2 . The sequences obtained with the 1492r primer gave ambiguous results: bacteria with the highest consensus score corresponded to the targeted species, L. amylolyticus, but were not significantly different from the bacteria with the second highest score, the closely related species L. amylovorus. The primers 16S-27r, 612r, and 926r were then additionally used for the $16 \mathrm{~S}$ rDNA gene sequencing. According to the obtained sequences, the bacteria were identified as L. amylolyticus. The 16S rDNA sequence obtained from strain L. amylolyticus SG117 was deposited in the Genbank database under the accession number KT 891013. All selected strains can be identified at species level.

Table 2. Overview of the identified bacterial and yeast strains using the $16 \mathrm{~S}$ and $26 \mathrm{~S}$ rDNA gene sequencing, respectively.

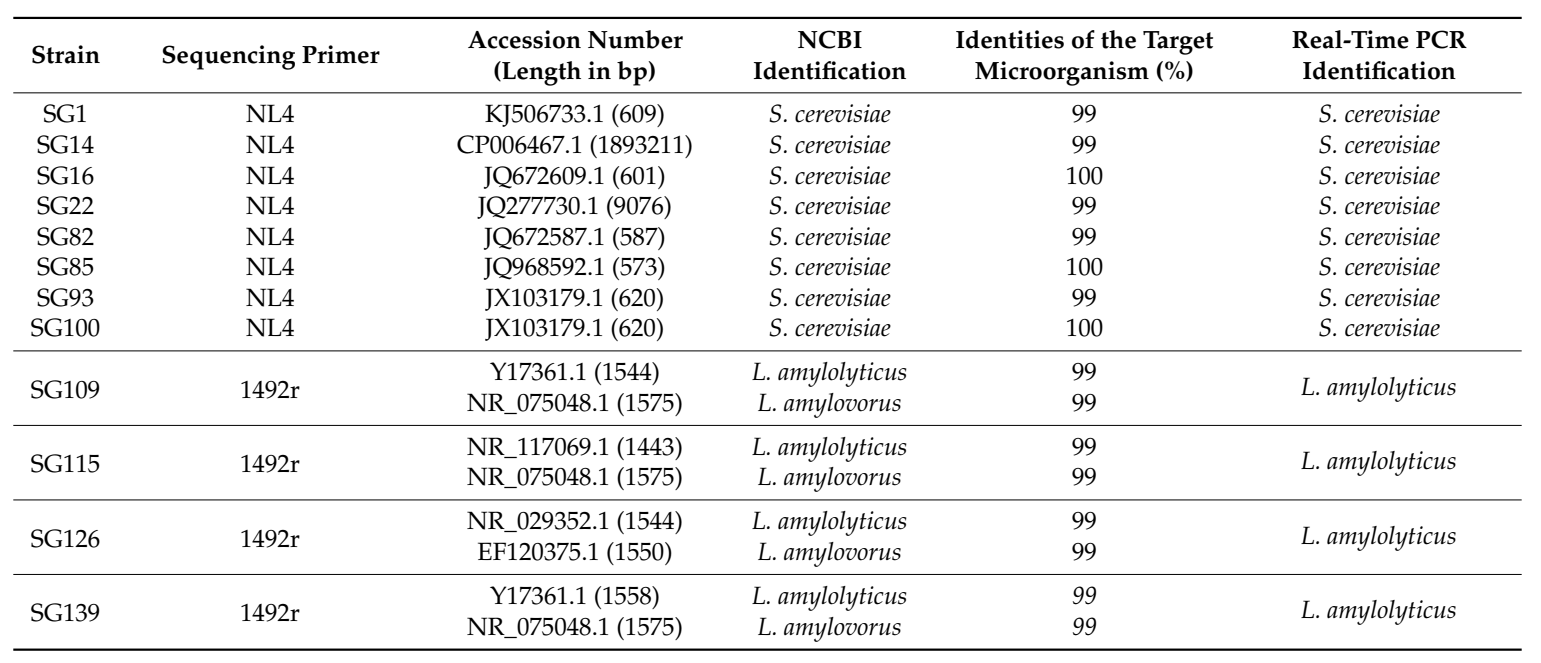


The identification of bacteria at the species level, L. amylolyticus, was confirmed by real-time PCR, according to Brandl [20]. All of the 28 samples were determined to be L. amylolyticus.

\subsection{Identification of Yeasts}

On the basis of the phylogenetic trees of IGS2 314 (Figure 2), the 10 most differing yeasts were chosen for further analyses (SG1, SG14, SG16, SG22, SG82, SG85, SG93, and SG100). The primer NL4 was used for the 26S rDNA gene sequencing of the isolated yeast species. The results of BLAST are shown in Table 2, and all of the 10 yeast samples were identified as S. cerevisiae. For the BLAST analysis of the sequence $26 \mathrm{~S}$ rDNA, the yeast with the highest consensus score corresponded to the yeast of detection and was significantly different from the yeast species with the second-highest score. All of the selected yeast strains could be identified at the species level. Moreover, differentiation was established between the top-fermenting (S. cerevisiae) and bottom-fermenting (S. pastorianus) yeast (Table 3), according to Hutzler [15] and Salinas et al. [21]. All the selected samples were confirmed to be S. cerevisiae. As wild S. cerevisiae strains are mostly able to produce phenolic off-flavors (POF), their ability to decarboxylase cinnamic acid and ferulic acid to the corresponding flavor components was analyzed $[24,25]$. The results can be reviewed in Table 4 . They show that the strains vary in their ability to produce phenolic off-flavors. Strains SG16 and SG29 do not produce any phenolic off-flavors, in contrast to the other analyzed strains.

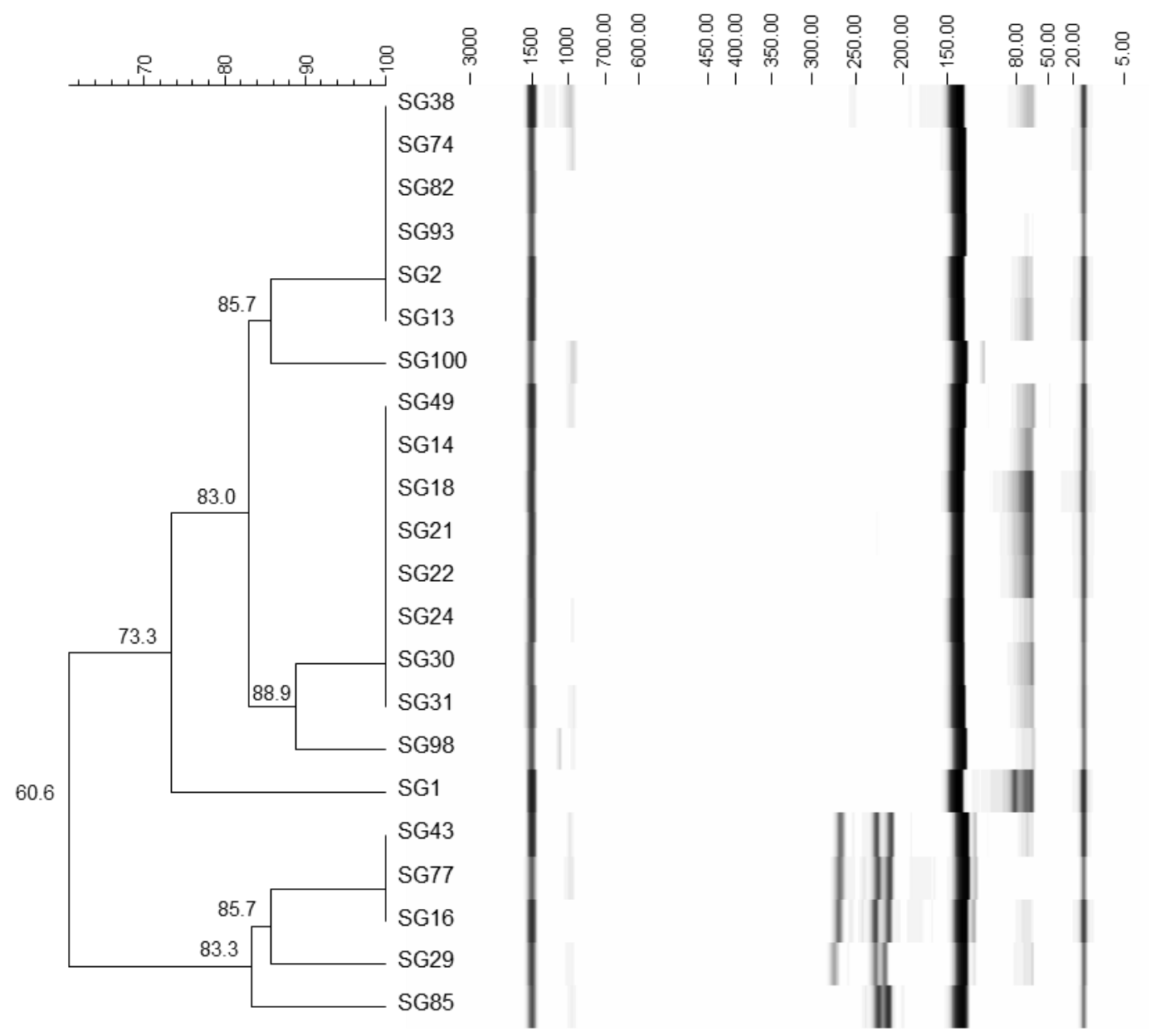

Figure 2. Phylogenetic tree (IGS2 314 region) of the 22 yeast strains detected in a sample of acidified wort from a plant run continuously for 20 years, and identified by sequencing ( $26 \mathrm{~S}$ rDNA) as S. cerevisiae. 
Table 3. Results of the real-time PCR differentiation between top- (OG-COXII and SCTM) and bottom-fermenting (UG-LRE1; UG300 and Sbp) yeasts (+ = positive PCR reaction; - = negative PCR reaction).

\begin{tabular}{cccccc}
\hline Yeast Strain & OG-COXII & SCTM & UG-LRE1 & UG300 & Sbp \\
\hline S. cerevisiae SG1 & + & + & - & - & - \\
S. cerevisiae SG14 & + & + & - & - & - \\
S. cerevisiae SG16 & + & + & - & - & - \\
S. cerevisiae SG22 & + & + & - & - & - \\
S. cerevisiae SG82 & + & + & - & - & - \\
S. cerevisiae SG85 & + & + & - & - & - \\
S. cerevisiae SG93 & + & + & - & - & - \\
S. cerevisiae SG100 & + & + & - & - & - \\
\hline
\end{tabular}

Table 4. Results of the phenolic off-flavor (POF) test performed with eight of the investigated strains and two reference strains (Frisinga-TUM $34 / 70^{\circledR}$ POF negative and LeoBavaricus-TUM $68^{\circledR}$ POF positive).

\begin{tabular}{|c|c|c|}
\hline Yeast & $\begin{array}{c}\text { Precursor Cinnamic Acid, } \\
\text { Product Styrene } \\
\text { "Styrofoam-Like" }\end{array}$ & $\begin{array}{c}\text { Precursor Ferulic Acid, } \\
\text { 4-Vinylguaiacol } \\
\text { "Clove-Like" }\end{array}$ \\
\hline Frisinga-TUM $34 / 70^{\circledR}$ & - & - \\
\hline LeoBavaricus-TUM $68^{\circledR}$ & + & + \\
\hline S. cerevisiae SG1 & ++ & + \\
\hline S. cerevisiae SG14 & ++ & + \\
\hline S. cerevisiae SG16 & - & - \\
\hline S. cerevisiae SG22 & ++ & + \\
\hline S. cerevisiae SG24 & ++ & + \\
\hline S. cerevisiae SG29 & - & - \\
\hline S. cerevisiae SG82 & ++ & ++ \\
\hline S. cerevisiae SG85 & ++ & ++ \\
\hline
\end{tabular}

\section{Discussion}

The identification of yeast and lactic acid bacteria found in the sample of a biological acidification plant continuously run for 20 years uncovered two main species. The yeast species $S$. cerevisiae was detected with a variety of differing strains, as shown in Figure 2 and Table 4 . Some of them were POF-positive as well as POF-negative, suggesting that a certain number of the strains might have been present for some time. All yeast strains are considered as spoilers in a biological acidification plant $[5,6]$; however, the presence of POF-negative S. cerevisiae strains suggests these were present for a long time, as a missing ability to produce phenolic off-flavors is a link to the domestication process [26]. A comparison of the yeast fingerprints (Figure 2, IGS2 314) with the IGS2 314 fingerprint of the culture yeast of the brewery showed low equality (data not shown), excluding the eventual case of a contamination by the applied culture brewing yeast. The acidified wort, however, did not have a phenolic off-flavor, which indicates a low contamination of the yeast strains. A contamination with cell counts higher than $1 \times 10^{4}$ cell $/ \mathrm{mL}$ would show a phenolic off-flavor in the produced wort [27]. The low $\mathrm{pH}$ value of the wort ( $\mathrm{pH}$ value of approximately 3.2) and the high temperatures $\left(>45^{\circ} \mathrm{C}\right)$ might have lowered the growth potential of the S. cerevisiae strains [9].

The presence of differing strains of the species L. amylolyticus, but no other detected bacteria species, shows a potential mutation of the original pure culture, or that the original culture was already a strain mixture (strain mixtures were often popular in biological acidification plants in the 1980s and 1990s). The phylogenetic tree of the $\left((\mathrm{GTG})_{5}\right)$ fingerprints suggests three main clusters with very high similarity. The change from the mixed culture to a pure culture changed the taste of the product 
significantly. This showed that the different strains had an impact on the flavor. A re-inoculation with the old mixed culture produced the same taste as before, suggesting that the differing strains influence the flavor (as reported by the brewery).

\section{Conclusions}

In a biological acidification process that has run continuously for 20 years, only strains of the inoculated species Lactobacillus amylolyticus could be cultivated, and no cross-contamination by other LAB species could be analyzed. Lactobacillus amylolyticus was also the initial starter culture species. Thus, it could be confirmed that only strains of species Lactobacillus amylolyticus could be identified, and that they belonged to the same species that was initially inoculated 20 years ago. Only Lactobacillus amylolyticus strains could be identified, and no other LAB species could be cultivated. Minor contamination with yeast might not be averted, but as shown, their growth rate can be described as low, because a $\mathrm{pH}$ value of around 3 and temperatures at $48{ }^{\circ} \mathrm{C}$ will keep the spoilage under control. However, the small change in the culture and resulting variation in the strains, as shown in the phylogenetic tree in Figure 1, has an impact on the flavor and the "in-house taste" of the final beer. A new set up with a pure culture of one of the present L. amylolyticus strains produced a considerably different taste to the mixture of all the strains (as reported by the brewery).

Author Contributions: M.H. and J.C. designed and performed the experiments, analyzed the data and wrote the paper, M.H. designed Real-Time PCR probes and optimized PCR-sequencing and PCR fingerprinting tools. A.B. designed primer and probes for LAB and modified DNA extraction methods, T.F. took the wort acdification samples and provided historical facts, practical data and strain related data about the wort acidification process at the Ottakringer brewery, Vienna, Austria. F.J. contributed reagents/materials/analysis tools/ hardware and revised the conception. M.M. wrote the paper and performd bioinformatic analysis and revised the conception and manuscript.

Funding: The results were obtained with the support of the Ministry of Education, Youth and Sports of the Czech Republic-Research Sensory Center in Prague, and the Research and Development Center-Sustainability and Development (LO1312).

Acknowledgments: The results were obtained with the support of the Ministry of Education, Youth and Sports of the Czech Republic-Research Sensory Center in Prague, and the Research and Development Center-Sustainability and Development (LO1312). We like to thank Margit Grammer, Anna Kleucker, Veronika Kaindl and Dominique Stretz who took care about the strains in the culture collection of the Research Center Weihenstephan for Brewing and Food Quality (TUM).

Conflicts of Interest: The authors declare no conflict of interest.

\section{References}

1. Back, W. Biologische Säuerung. Monatsschr. Brauwiss. 1988, 41, 152-156.

2. Lindner, P. Über ein neues in Malzmaischen vorkommendes Milchsäure bildendes Ferment. Wochenschr. Brau. 1887, 4, 437-440.

3. Leichmann, G. Über die im Brennereiprozeß bei der Bereitung von Kunsthefe auftretende spontane Milchsäuregarung (Bac. Delbrücki). Zentralbl. Bakteriol. 1896, 2, 281-285.

4. Francke, O. Herstellung säuerlich schmeckender, insbesondere milchsauerer Biere. Deutsches Reichspatent Nr. 180726, 5 April 1906.

5. Oliver-Daumen, B. Biological acidification in the brewing process-Part 1: Review of the literature. Brauwelt Int. 1988, 256-264.

6. Grützmacher, J. Biologische Säuerung in der Brauerei. Brauwelt 1991, 40, 1762-1769.

7. Back, W. Ausgewählte Kapitel der Brauereitechnologie; Hans Carl: Nürnberg, Germany, 2005.

8. Lowe, D.P.; Ulmer, H.M.; Barta, R.C.; Goode, D.L.; Arendt, E.K. Biological Acidification of a Mash Containing 20\% Barley Using Lactobacillus amylovorus FST 1.1: Its Effects on Wort and Beer Quality. J. Am. Soc. Brew. Chem. 2005, 63, 96-106. [CrossRef]

9. Lowe, D.P.; Arendt, E.K. The Use and Effects of Lactic Acid Bacteria in Malting and Brewing with Their Relationships to Antifungal Activity, Mycotoxins and Gushing: A Review. J. Inst. Brew. 2004, 110, 163-180. [CrossRef] 
10. Vaughan, A.; O'Sullivan, T.; Sinderen, D. Enhancing the Microbiological Stability of Malt and Beer-A Review. J. Inst. Brew. 2005, 111, 355-371. [CrossRef]

11. Bohak, I.; Back, W.; Richter, L.; Ehrmann, M.; Ludwig, W.; Schleifer, K.H. Lactobacillus amylolyticus sp. nov., Isolated from Beer Malt and Beer Wort. Syst. Appl. Microbiol. 1998, 21, 360-364. [CrossRef]

12. Goranov, B.; Denkova, Z.; Kostov, G.; Denkova, R. Possibilities for the biological acidification of mash in the production of wort: Kinetics of lactic acid production in a free cell culture of Lactobacillus delbrueckii ssp. bulgaricus M3. Presented at 50 Years FoodRDI. Food Technologies and Health, International Scientific-Practical Conference, Plovdiv, Bulgaria, 8 November 2012.

13. Boulton, C.; Quain, D. Brewing Yeast and Fermentation; Blackwell Science; Iowa State University Press: Malden, MA, USA; Ames, IA, USA, 2001.

14. Versalovic, J.; Schneider, M.; de Bruijn, F.J.; Lupski, J.R. Genomic fingerprinting of bacteria using repetitive sequence-based polymerase chain reaction. Methods Mol. Cell. Biol. 1994, 5, 25-40.

15. Hutzler, M. Getränkerelevante Hefen-Identifizierung und Differenzierung. Wie Können Hefen Praxisrelevant Unterschieden Werden, und wie Können Identifizierungsergebnisse Technologisch Bewertet Werden? Südwestdt. Verlag für Hochschulschriften: Saarbrücken, Germany, 2010; ISBN-13: 9783838114828.

16. Zhang, H.; You, C.; Ren, J.; Xu, D.; Han, M.; Liao, W. A simple one-step PCR walking method and its application of bacterial rRNA for sequencing identification. Curr. Microbiol. 2014, 68, 254-261. [CrossRef] [PubMed]

17. Ehrmann, M.A.; Müller, M.R.A.; Vogel, R.F. Molecular analysis of sourdough reveals Lactobacillus mindensis sp. nov. Int. J. Syst. Evol. Microbiol. 2003, 53, 7-13. [CrossRef] [PubMed]

18. Nossa, C.W.; Oberdorf, W.E.; Yang, L.; Aas, J.A.; Paster, B.J.; Desantis, T.Z.; Brodie, E.L.; Malamud, D.; Poles, M.A.; Pei, Z. Design of $16 \mathrm{~S}$ rRNA gene primers for 454 pyrosequencing of the human foregut microbiome. World J. Gastroenterol. 2010, 16, 4135-4144. [CrossRef] [PubMed]

19. Kurtzman, C.P.; Robnett, C.J. Phylogenetic relationships among yeasts of the 'Saccharomyces complex' determined from multigene sequence analyses. FEMS Yeast Res. 2003, 3, 417-432. [CrossRef]

20. Brandl, A. Entwicklung und Optimierung von PCR-Methoden zur Detektion und Identifizierung von Brauereirelevanten Mikroorganismen zur Routine-Anwendung in Brauereien. Ph.D. Thesis, TU München, Freising, Germany, 2006.

21. Salinas, F.; Garrido, D.; Ganga, A.; Veliz, G.; Martínez, C. Taqman real-time PCR for the detection and enumeration of Saccharomyces cerevisiae in wine. Food Microbial. 2009, 26, 328-332. [CrossRef] [PubMed]

22. Meier-Dörnberg, T.; Hutzler, M.; Michel, M.; Methner, F.-J.; Jacob, F. The Importance of a Comparative Characterization of Saccharomyces Cerevisiae and Saccharomyces Pastorianus Strains for Brewing. Fermentation 2017, 3, 41. [CrossRef]

23. Stackebrand, E.; GOEBEL, B.M. Taxonomic Note: A Place for DNA-DNA Reassociation and 16S rRNA Sequence Analysis in the Present Species Definition in Bacteriology. Int. J. Syst. Evol. Microbiol. 1994, 44, 846-849. [CrossRef]

24. Thurston, P.A.; Tubb, R.S. Screening yeast strains for their ability to produce phenolic off-flavours: A simple method for determining phenols in wort and beer. J. Inst. Brew. 1981, 87, 177-179. [CrossRef]

25. Gallone, B.; Steensels, J.; Prahl, T.; Soriaga, L.; Saels, V.; Herrera-Malaver, B.; Merlevede, A.; Roncoroni, M.; Voordeckers, K.; Miraglia, L.; et al. Domestication and divergence of Saccharomyces cerevisiae beer yeasts. Cell 2016, 166, 1397-1410. [CrossRef] [PubMed]

26. Goncalves, M.; Pontes, A.; Almeida, P.; Barbosa, R.; Serra, M.; Libkind, D.; Hutzler, M.; Goncalves, P.; Sampaio, J.P. Distinct domestication trajectories in top-fermenting beer yeasts and wine yeasts. Curr. Biol. 2016, 26, 2750-2761. [CrossRef] [PubMed]

27. Röcken, W.; Marg, C. Nachweis von Fremdhefen in der obergärigen Brauerei. Vergleich verschiedener Nährböden. Monatsschr. Brauwiss. 1983, 1983, 276-279.

(C) 2018 by the authors. Licensee MDPI, Basel, Switzerland. This article is an open access article distributed under the terms and conditions of the Creative Commons Attribution (CC BY) license (http://creativecommons.org/licenses/by/4.0/). 